\title{
AKTIVITAS KATEKIN TERHADAP STABILISASI PLAK (DALAM RANGKA MEMPERKECIL RESIKO SERANGAN JANTUNG)
}

\author{
Erna Susanti, SSi, M.Biomed, Apt \\ Akafarma Putra Indonesia Malang \\ e-mail: rna_far@yahoo.co.id
}

\begin{abstract}
Abstrak
Tujuan penelitian ini adalah membuktikan efek katekin teh hijau terhadap peng-hambatan peningkatan ekspresi MMP9 pada tikus wistar jantan dengan diet tinggi lemak. Metode yang digunakan pada penelitian ini terdiri ELISA untuk pengukuran ekspresi MMP9. Hasil penelitian menunjukkan bahwa katekin menghambat peningkatan ekspresi MMP9 pada dosis $6 \mathrm{mg} /$ hari dan $24 \mathrm{mg} /$ hari secara bermakna tetapi tidak untuk dosis 3mg / hari. Ini menunjukkan dosis 6mg/ hari dan 24 mg / hari mampu memperbaiki keru-sakan pensinyalan insulin pada jalur MAPK yang disebabkan oleh resistensi insulin. Hasil ini didasarkan pada kemampuan katekin sebagai antioksidan. Dari hasil penelitian dapat disimpulkan katekin menghambat peningkatan ekspresi MMP9 pada dosis $6 \mathrm{mg} /$ hari dan $24 \mathrm{mg} / \mathrm{hari}$ dan dapat dikembangkan sebagai agen ateroprotektif untuk stabilisasi plak sehingga dapat mencegah resiko serangan jantung.

Kata kunci : katekin teh hijau, ekspresi MMP9, tikus wistar jantan, diet tinggi lemak, stabilisasi plak
\end{abstract}

\section{Pendahuluan}

Penyakit Jantung Koroner (PJK) merupa-kan penyebab mortalitas dan morbiditas yang cu-kup tinggi. Berdasarkan data WHO diperkirakan 3,8 juta pria dan 3,4 juta wanita di seluruh dunia setiap tahun meninggal karena PJK. Atherosklero-sis merupakan kontributor utama terhadap patogenesis terjadinya penyakit jantung koroner yang menjadi penyebab utama kematian (World Health Organization, 2003).

Serangan jantung merupakan salah satu gejala terjadinya penyumbatan atau gangguan pa-da pembuluh darah pada jantung. Gangguan terse-but disebabkan terjadinya pengerasan pembuluh darah yang lebih dikenal dengan atherosklerosis. Pada atherosklerosis terjadi pengerasan dinding arteri akibat penimbunan berbagai komponen ter-masuk lipid, kolesterol dan garam kalsium yang mengakibatkan arteri menjadi kaku. Proses ini akhirnya akan menyebabkan penyempitan lumen arteri.

Salah satu faktor resiko yang menyebab-kan progesifitas atherosklerosis adalah dislipide-mia. Diet tinggi lemak dan obesitas merupakan salah satu pencetus dislipidemia. Dislipidemia da-pat memicu terjadinya inflamasi kronik yang di-sebabkan karena peningkatan sitokin proinflamasi antara lain C- Reaktif Protein (CRP) dan Interleu-kin6 (IL-6) yang akan mengakibatkan disfungsi endotel. Disfungsi endotel berperan penting pada pathogenesis dari atherosklerosis lebih utama di-sebabkan karena deregulasi aktivitas enzimatis eNOS dan inaktivasi NO oleh stress oksidatif. eNOS uncoupling merupakan mekanisme penting yang berkontribusi terhadap peningkatan stress oksidatif pada atherosklerosis (Yang Z dan Ming XF, 2006). eNOS uncoupling merupakan suatu kondisi yang memicu terbentuknya anion super-oksid $\left(\mathrm{O}_{2}{ }^{-}\right)$dan berkurangnya pelepasan NO. Yang $\mathrm{Z}$ dan Ming XF (2006) juga menyatakan bahwa anion superoksid beserta enzim-enzim yang lain bereaksi dengan NO menjadi oksidan peroksinitrit yang lebih poten yang akan mengin-aktifkan tetrahydro Biopterin $\left(\mathrm{BH}_{4}\right)$, suatu kofaktor yang diperlukan untuk mengubah L- arginin menjadi NO serta meningkatkan akumulasi Asymetric Dimethylarginin (ADMA) suatu endogenus inhibitor eNOS. Kondisi inilah yang memicu terjadinya disfungsi endotel yang menjadi awal dari atherogenesis.

Selain menyebabkan disfungsi endotel, adanya akumulasi metabolit toksik lemak yaitu fatty acyl CoA, diacylglycerol, ceramide pada ja-ringan termasuk juga pada arteri akan menyebab-kan terjadinya resistensi insulin karena metabolit tersebut akan merusak sinyal insulin dan metabo-lisme glukosa. Kondisi ini juga akan memicu per-cepatan terjadinya atherosklerosis (DeFronzo , 2009). Pada kondisi resistensi insulin terjadi gangguan 
sinyal tranduksi insulin yang melibat-kan dua jalur utama yaitu PI3K dan MAPK (Hsueh and Law, 2001).

Aktivasi jalur PI3K pada endotel akan mengaktivasi eNOS yang menghasilkan NO seba-gai vasodilator serta mengaktivasi guanylate cy-clase untuk meningkatkan kadar cGMP yang me-micu relaksasi otot polos vaskuler. Sedangkan aktivasi jalur MAPK akan meningkatkan produksi endotelin-1 (ET-1) suatu vasokonstriktor, aktivasi pompa kation serta peningkatan ekspresi VCAM-1. Pada kondisi resistensi insulin akan menyebab-kan terjadi penurunan pada pensinyalan PI3K dan sebaliknya terjadi peningkatan pada jalur MAPK. Stimulasi terus menerus pada jalur MAPK akan menyebabkan proliferasi VSMC, peningkatan pembentukan kolagen, produksi berlebihan growth faktor dan sitokin proinflamasi yang ber-kontribusi terhadap percepatan terjadinya atherosklerosis. (DeFronzo, 2006). Selain beberapa hal di atas, MMP-9- suatu enzim yang berperan untuk stabilisasi plak aterosklerosis berperan penting agar plak yang telah terbentuk tidak pecah yang akhirnya dapat ikut dalam aliran darah dan menyebabkan terjadinya penyumbatan pada pembuluh darah.

Salah satu bahan alam yang berpotensi sebagai antioksidan adalah katekin yang diisolasi dari tanaman teh (Camellia sinensis). Lembaga Penelitian Teh dan Kina Gambung telah mengem-bangkan klon tanaman teh yaitu klon GMB4 dengan kadar katekin lebih tinggi daripada ta-naman teh lainnya. Spesifisitas struktur kimia be-berapa komponen dalam isolat ini antara lain jum-lah hidroksi fenolik dan gugus galoilnya serta struktur epimerisasinya berpengaruh terhadap aktivitasnya meskipun kadar katekin total sama. Beberapa penelitian yang mendukung aktivitas katekin teh terhadap fungsi vaskuler diantaranya penelitian Anter et al., (2004) yang menunjukkan bahwa fraksi polifenol dari black tea menstimula-si aktivitas katalitik eNOS yang membuktikan bahwa terdapat bukti kuat keterlibatan NO dalam menginduksi vasorelaksasi dari polifenol teh.

Gugus hidroksi fenolic pada katekin berpe-ran terhadap penangkapan radikal bebas, peng-hambatan lipid peroksidasi dan hidrolisis lemak sedangkan struktur galloilnya berperan terhadap produksi prostasiklin, pengurangan ekspresi VCAM-1 dan penghambatan proliferasi VSMC (Velayutham and Liu, 2008).
Berdasarkan data penelitian di atas maka perlu dilakukan penelitian untuk membuktikan efek pemberian isolat golongan senyawa katekin teh hijau Klon GMB 4 dengan berbagai dosis ter-hadap ekspresi MMP-9 sehingga dapat diprediksi pengaruhnya pada pencegahan atherosklerosis dan penyakit kardiovaskular.

\section{Bahan dan Cara Kerja}

Penelitian ini termasuk penelitian eksperi-mental dengan desain penelitian menggunakan Control Group Post Test Design - Penentuan ob-jek penelitian dengan Rancangan Acak Lengkap dengan lima perlakuan, yaitu ( 1 ) Tikus dengan diet pakan standart ( 2 ) Tikus dengan diet tinggi lemak, ( 3 ) Tikus dengan diet tinggi lemak + katekin 3 $\mathrm{mg} / \mathrm{hari}(4)$ Tikus dengan diet tinggi lemak + katekin $6 \mathrm{mg} /$ hari ( 5 ) Tikus dengan diet tinggi lemak + katekin $24 \mathrm{mg} /$ hari. Perlaku-an dilaksanakan selama 60 hari. Tikus dibedah setelah 60 hari perlakuan diambil jaringan aortanya.

Penelitian dilakukan di Laboratorium Ilmu Faal Fakultas Kedokteran Universitas Brawi-jaya Malang pada bulan Juni 2010 sampai dengan Maret 2011. Sampel yang digunakan adalah tikus percobaan berjumlah 25 ekor sesuai dengan kri-teria inklusi dan eksklusi sebagai berikut, kriteria inklusi : Tikus jenis Rattus norvegicus strain wistar, jenis kelamin jantan, umur 6 - 8 minggu, berat badan antara 130 gram s.d. 155 gram, warna bulu putih tikus aktif dan kriteria eksklusi : tikus yang tidak mau makan dan tikus yang mengalami penurunan keadaan fisik atau mati.

Pakan tikus diberikan secara oral, sedang-kan katekin diberikan melalui sonde. Pakan stan-dart yang terdiri dari pakan ayam (dengan kan-dungan air, protein, lemak, serat, abu, Ca, Phospor, antibiotika, coccidiostat) $66,6 \%$ dan te-pung terigu 33,4\%. Diet tinggi lemak yang terdiri dari pakan standart (pakan ayam $57,3 \%$ dan te-pung terigu $31,8 \%$ ) ditambah kolesterol 1,9\%, asam kolat $0,1 \%$ dan minyak babi 8,9\%. ( Ali M, 2004 )

Pengukuran ekspresi MMP-9 dilakukan dengan metode ELISA sebagai berikut, pertama adalah menentukan jumlah well yang digunakan pada microtiter. Untuk pembuatan kurva standar, dipipet $100 \mu \mathrm{l}$ assay buffer dalam sumuran ( seba-gai blank well), dipipet $100 \mu \mathrm{l}$ antibody MMP9 standar 1-7 ke dalam well yang telah ditentukan. Sampel jaringan 
aorta diisolasi proteinnya terlebih dahulu dengan menggunakan buffer RIPA. Hasil isolasi protein ini digunakan untuk pengukuran ekspresi MMP-9. Untuk sampel perlakuan, hal yang dilakukan adalah memipet $100 \mu$ sampel per-lakuan dan dimasukkan ke dalam well. Mikrotiter diinkubasi pada suhu $37{ }^{\circ} \mathrm{C}$ selama 2 jam. Masing- masing well dicuci dengan wash buffer 3x $400 \mu \mathrm{l}$. Masing- masing well diisi dengan $100 \mu$ l conjugate kecuali pada blanko.

Microtiter diinkubasi pada suhu $37^{\circ} \mathrm{C}$ se-lama 30 menit. Masing- masing well dicuci deng-an wash buffer $3 x 400 \mu$ l. Substrat TMB dipipet sebanyak $100 \mu \mathrm{l}$ dan dimasukkan pada masing- masing well, selanjutnya diinkubasi selama 30 menit pada suhu ruang. Stop solution $(\mathrm{HCl})$ dipipet sebanyak $100 \mu \mathrm{l}$ dan dimasukkan pada masing- masing well selama 5 menit. Pembacaan nilai absorbansi dilakukan pada OD 492 nm. (Aulaniam, 2004 )

Analisis data menggunakan one-way ANOVA dilanjutkan dengan Uji Tukey untuk me-lihat perbedaan masing- masing variabel. Analisis data dilakukan dengan komputerisasi mengguna-kan program SPSS for Windows versi 17.

\section{Hasil dan Pembahasan}

Perubahan berat badan tidak berbeda ber-makna antar perlakuan sedangkan asupan pakan masing- masing kelompok perlakuan secara umum tidak menunjukkan perbedaan yang ber-makna kecuali pada masing- masing kelompok perlakuan dengan kelompok katekin dosis II.

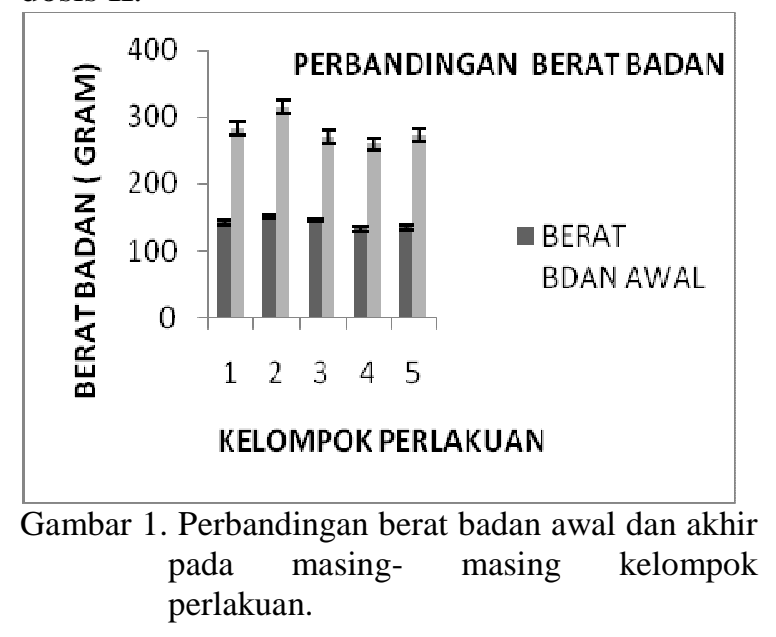

Pemberian diet tinggi lemak ini selama 8 minggu bertujuan untuk menginduksi terjadinya resistensi insulin. Penelitian Schrauwen, ( 2007 ) menunjukkan bahwa ketidakseimbangan asupan energi dengan penggunaannya mengakibatkan terjadinya positif fat balance. DTL merupakan makronutrien yang padat energy kira- kira 38 $\mathrm{KJ} / \mathrm{g}$ ( dengan komposisi $\mathrm{KH}$ dan protein sebesar $17 \mathrm{KJ} / \mathrm{g}$ ). Peningkatan intake DTL meningkatkan intake energy diet, menyebabkan positif energi balance dan sebagai konsekuensinya terjadinya positif fat balance. Kondisi ini yang menyebabkan tingginya kadar FFA yang dapat menstimulasi resistensi insulin. Pada vascular tingginya kadar FFA ini menginisiasi beberapa proses seluler yaitu kerusakan signaling insulin, stress oksidatif, peningkatan local RAAS ( Renin Angiotensin Aldosteron System ) dan peningkatan sensitivitas adrenergik VSMC. RAAS merupakan system hormon yang meregulasi tekanan darah dan keseimbangan cairan ( air ). Ketika volume darah rendah, sel juxtaglumerular di ginjal mensekresi renin. Renin menstimulasi produksi Angiotensin I yang kemudian dikonversi menjadi angiotensin II. Angiotensin II menyebabkan konstriksi pembuluh darah. Angiotensin II juga menstimulasi sekresi hormon aldosteron dari korteks adrenal. Aldosteron menyebabkan tubulus ginjal meningkatkan reabsorbsi $\mathrm{Na}$ dan air dalam darah. Kondisi ini akan meningkatkan volume cairan di dalam tubuh yang otomatis meningkatkan tekanan darah. Selain itu peningkatan FFA oksidasi akan meningkatkan intramitokondrial acetyl CoA / CoA \& $\mathrm{NADH} / \mathrm{NAD}^{+}$rasio yang selanjutnya menginaktifkan piruvate dehidrogenase. Ini menyebabkan konsentrasi sitrat meningkat yang memicu penghambatan fosfofruktokinase yang selanjutnya terjadi akumulasi G-6 fosfat.

Akhirnya peningkatan konsentrasi G-6 fosfat ini akan menghambat hexokinase II yang menyebabkan penurunan glukosa uptake ( Roden , et.al.1996 ). Penelitian DeFronzo, ( 2010 ) . menunjukkan bahwa intraseluler metabolit toksik dari metabolit triasilgliserol dan NEFA ( Non Esterified Fatty Acid ) yaitu fatty acyl CoA, Diasilgliserol (DAG), ceramide menyebabkan resistensi insulin yang lebih berat dengan jalan merusak jalur signaling insulin dan banyak tahapan metabolisme glukosa intraseluler.

Mekanisme lain yang dapat dijelaskan adalah menurut Kim J and Sears D. 2010 menunjukkan bahwa TLR4 ( Toll- Like Reseptor 4 ) merupakan mediator penting resistensi insulin serta inflamasi melalui aktivasi oleh ligan salah satunya adalah asam 
laurat, suatu FFA yang dapat mengalami peningkatan dengan pemberian diet tinggi lemak. TLR4 diekspresikan pada semua sel termasuk sel target insulin dapat mengaktivasi proinflamatory kinases JNK, IKK dan p38 yang merusak sinyal tranduksi insulin secara langsung melalui penghambatn fosforilasi IRS pada residu serin. Aktivasi TLR4 juga memicu peningkatan transkripsi gen proinflamasi yang menghasilkan peningkatan sitokin, kemokin, ROS dan kadar eicosanoid yang mengarah pada desensitisasi insulin pada sel target itu sendiri maupun sel lain melalui parakrin dan efek sistemik. FFA juga dilaporkan berikatan dan mengaktivasi TLR4. Dua jalur sinyaling yang diaktivasi TLR4 adalah melalui MyD88 dan TIRAP yang mengaktivasi IKK, p38, JNK, CREB, AP2 dan NFkB yang menginduksi gen proinflamasi. Jalur lain melalui TRAM dan TRIF yang mengaktivasi IKK, NFkB dan IRF3 yang menginduksi gen interferon type 1 . Aktivasi transkripsional pada jalur ini menginduksi ekspresi ratusan gen yang terlibat dalam mekanisme pertahanan dari sistem imun. Jalur yang teraktivasi oleh TLR4 ini menghambat system sinyaling yang lain seperti sinyal insulin melalui fosforilasi serin IRS-1. Palmitat juga dapat mengaktivasi TLR4, pada aorta palmitat meningkatkan aktivitas IKK $\beta$ dan mengurangi sinyaling insulin dan aktivitas eNOS. Pada kultur sel endotel berkurangnya sinyaling IRS-1 dan aktivitas eNOS yang diinduksi oleh palmitat tergantung pada masing- masing protein kunci pada jalur sinyaling TLR4 yaitu TLR4, MyD88, IRAK, IKK $\beta$ dan $N F k \beta$. Aktivasi $N F k \beta$ menghambat fosforilasi tyrosin IRS-1 melalui mekanisme yang belum jelas. Beberapa kandidat mediator penghambatan sinyaling IRS-1 yang diperantarai NFk $\beta$ adalah S6 kinase, mTOR ( mammalian target of rapamycyn ), suppressor of cytokine Signaling ( SOCS3 ), c- JUN-NH2 ( JNK ), Akt dan beberapa isoform PKC. Masing masing enzim ini mempunyai kemampuan untuk menghambat sinyaling IRS-1 dengan fosforilasi satu atau lebih dari residu serin 70 IRS-1 , suatu modifikasi IRS-1 yang diketahui merusak sinyaling IRS-1. ( Kim F, 2007 ).

Melalui jalur ROS dijelaskan bahwa dengan peningkatan ROS baik karena peningkatan FFA juga dari peningkatan respirasi mitokondria akan memicu aktivasi stress activated protein kinases yang menyebabkan peningkatan fosforilasi serin dan penurunan fosforilasi tirosin pada IRS-1.
Sedangkan melalui jalur PKC, peningkatan FFA akan meningkatkan aktivitas PKC yang berakibat juga pada peningkatan fosforilasi serin pada IRS-1. ( Pederson, et al , 2001).

Pada penelitian ini dilakukan pengukuran berat badan tikus setiap minggu serta perhitungan asupan pakan masing- masing kelompok perlakuan. Data tersebut diperlukan untuk konfirmasi apakah terjadinya perubahan secara fisik ( perubahan berat badan ) juga menyebabkan perubahan secara biomolekuler yaitu ekspresi MMP 9. Pada kelompok perlakuan katekin dosis II menunjukkan bahwa asupan pakan tertinggi tetapi berat badannya paling rendah. Ini menunjukkan bahwa katekin dosis II mampu menurunkan berat badan meskipun asupan pakan banyak. Kondisi ini tentunya dapat dimanfaatkan sebagai treatmen untuk penurunan berat badan. Menurut Murase et al 2005 ,konsumsi katekin selama 10 minggu menstimulasi oksidasi lemak pada tikus BALB/C. Pada tikus Sprague Dawley model obeis, EGCG salah satu komponen dari katekin juga mampu menurunkan berat badan selama 4 minggu secara siknifikan. Pada model ini juga menunjukkan intake energy tidak berpengaruh terhadap berat badan. ( Klaus et al 2005 ) . Sementara Choo ( 2003) dalam penelitiannya menyimpulkan bahwa katekin teh hijau menurunkan lemak tubuh dan meningkatkan penggunaan energi melalui aktivasi $\beta$ adrenoreseptor. Kadar protein pada interscapular jaringan adiposa coklat juga meningkat. Kondisi ini menunjukkan peningkatan kapasitas termogenik.

Hasil pengukuran ekspresi MMP9 dengan metode ELISA adalah sebagai berikut :

\begin{tabular}{|lc|}
\multicolumn{1}{|c|}{ PERLAKUAN } & \multicolumn{1}{c|}{$\mathrm{PEAN} \pm \mathrm{SD}(\mu \mathrm{\mu g} / \mathrm{ml})$} \\
\hline Kontrol negatif & $408,100 \pm 39,26(\mathrm{c}$ \\
\hline Kontrol positif & $432,500 \pm 52,90\left(\mathrm{ab}^{2}\right.$ \\
\hline Katekin dosis I & $516,900 \pm 16,36\left(\mathrm{a}^{-}\right.$ \\
\hline Katekin dosis II & $407,700 \pm 26,26\left(\mathrm{bc}^{-}\right.$ \\
\hline Katekin dosis III & $410,700 \pm 11,33\left(\mathrm{ab}^{-}\right.$ \\
\hline
\end{tabular}

Keterangan : * Notasi yang berbeda menunjukkan perbedaan yang signifikan sedangkan notasi yang sama menunjukkan perbedaanyang tidak signifikan 


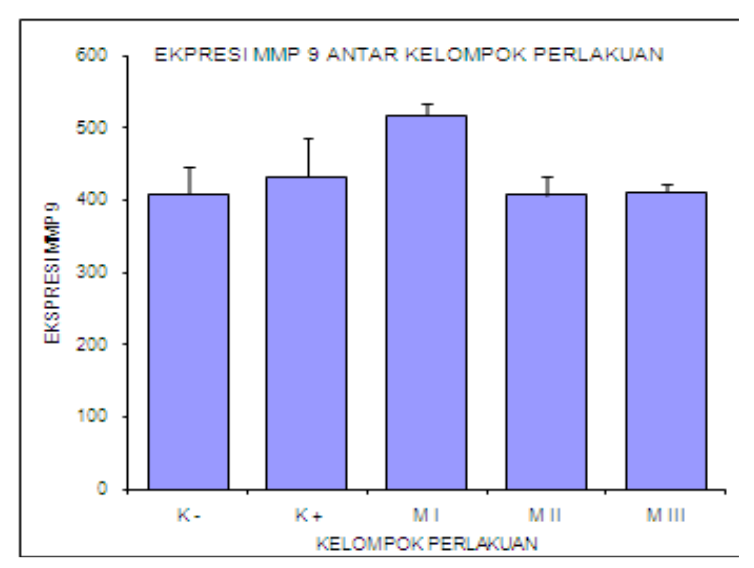

Gambar 2 . Hasil pengukuran ekspresi MMP 9 masing- masing kelompok perlakuan ( 1 ) kontrol negatif ( 2 ) kontrol positif ( 3 ) Katekin dosis I ( 4 ) katekin dosis II ( 5 ) katekin dosis III

Kontrol positif dengan diet tinggi lemak menunjukkan peningkatan ekspresi MMP 9 dibandingkan dengan kontrol negatif. Sedangkan katekin dosis II, III menunjukkan penghambatan peningkatan ekspresi MMP9 karena pemberian diet tinggi lemak. Sedangkan dosis I menunjukkan peningkatan ekspresi MMP 9 dibandingkan dengan kelompok pemberian diet tinggi lemak.

Berdasarkan analisis Anova ekspresi MMP 9, hasil $F_{\text {hitung }}=8,036$ dimana $F$ tabel dengan tingkat signifikansi 0,05 dengan df $1=4$ dan df2 $=12$ berdasarkan tabel sebesar 3,259. Karena $F_{\text {hitung }}>\mathrm{F}$ tabel maka Ho ditolak. Sedangkan berdasarkan sifnifikansi yang didapat sebesar 0,000 dimana nilai ini lebih kecil dari 0,05 maka Ho ditolak. Berdasarkan data di atas maka disimpulkan adanya perbedaan yang siknifikan ekspresi MMP 9 minimal dua kelompok perlakuan . Uji tukey menunjukkan kelompok perlakuan yang tidak berbeda secara bermakna dengan nilai $\mathrm{p}>$ 0,05 adalah kelompok perlakuan katekin dosis III dengan kontrol positif sedangkan kelompok perlakuan yang lain berbeda secara bermakna.

Katekin dosis II dapat dikatakan dosis yang optimal karena selain mampu menurunkan berat badan juga mampu menghambat peningkatan ekspresi MMP 9. Hasil penelitian menunjukkan bahwa diet tinggi lemak berpengaruh terhadap peningkatan ekspresi MMP 9 pada aorta hewan coba secara signifikan. Kondisi ini diduga terjadi stimulasi berlebihan pada jalur signaling MAPK. Produksi MMP9 pada makrofag diperantarai oleh kaskade asam arachidonat. Salah satu kunci pada kaskade tersebut adalah grup IVA PLA2 ( Phospholipase A2. Ox-LDL menginduksi peningkatan MMP9 ditandai dengan penurunan IVA PLA2 makrofag. Pemberian diet tinggi lemak menyebabkan tingginya ox- LDL sehingga menyebabkan tingginya ekspresi MMP9.

Beberapa Growth factor dan sitokin seperti basic Fibroblast Growth Factor ( bFGF), Platelet Derived Growth Factor ( PDGF ), TNF $\alpha$, IL-1 dapat menginduksi MMPs termasuk MMP1 ( colagenase ), MMP3 ( stromelysin ), MMP2 \& 9 ( kolagenase ) melalui aktivasi jalur MAPK yang meliputi ERK ( Ekstraseluler Regulated Protein Kinase ), JNK dan p38 MAPK.

ERK pathway diaktivasi oleh Growth Factor yang berhubungan dengan proliferasi sel, pertumbuhan sel, dan diferensiasi. Sementara JNK dan p38 MAPK yg dikenal juga dengan Stress Activated Protein Kinase diaktivasi secara kuat oleh rangsangan stress seperti shock osmotic, sinar UV dan sitokin. JNK dan p38 MAPK dihubungkan dengan apoptosis, cell survival, transformasi, perkembangan, migrasi sel serta aktivasi system imun. (Muniyappa R, et. al. 2007 )

Kelompok perlakuan dengan katekin dosis $6 \mathrm{mg} /$ hari dan $24 \mathrm{mg} / \mathrm{hari}$ mampu menghambat peningkatan ekspresi MMP9 . Perbedaan secara signifikan ditunjukkan oleh katekin dosis $6 \mathrm{mg} /$ hari. Sedangkan kelompok perlakuan katekin dosis $3 \mathrm{mg} /$ hari tidak menunjukkan penghambatan peningkatan ekspresi MMP 9 dibandingkan dengan kelompok perlakuan diet tinggi lemak. hasil ini kemungkinan disebabkan katekin dengan dosis $3 \mathrm{mg} /$ hari yang diberikan bersamaan dengan pemberian diet tinggi lemak belum mampu secara optimal menghambat efek yang timbul karena pemberian diet tinggi lemak.

Overekspresi dan aktivasi MMP 9 serta ketidakseimbangan antara MMPs aktif dengan TIMPs ( Tissue Inhibitor MetaloProteins ) merupakan faktor kunci pada pathogenesis penyakit yang disebabkan oleh pecahnya ECM ( Ekstra seluler matriks ). Terbentuknya plak dimulai dari disfungsi endotel yang menyebabkan terjadinya pelekatan monosit \& platelet ke endotel pembuluh darah. Selanjutnya terjadi migrasi monosit dari lumen ke intima media sementara sel otot polos bermigrasi dari media ke intima dan makrofag mengalami aktivasi. Makrofag mencerna lemak dan terjadi penimbunan lemak pada intima sehingga timbul 
plak. Sel otot polos juga mengalami proliferasi dan terjadi penumpukan ECM ( Ekstraceluler Matriks ) serta kolagen.

MMPs merupakan family proteases yang diproduksi oleh beberapa sel termasuk sel endotel, VSMC ( Vasculer Smooth Muscle Cells ) dan monosit. MMPs berperan utama pada degradasi kolagen dan komponen ECM lainnya. Aktivitas proteolitik enzim merupakan tahapan penentu kecepatan degradasi ECM. MMPs berperan pada semua tahapan proses aterosklerosis mulai dari inisiasi sampai dengan terjadinya rupture plak. Formasi plak terjadi sebagai hasil dari migrasi sel dan proliferasi disertai dengan akumulasi ECM. Ekspresi MMP9 dihubungkan dengan progesivitas dari rupture plak dan formasi intimal pada lesi arteri. MMP 9 diekspresikan setelah 6 jam setelah injuri pada arteri dan secara kontinyu diekspresikan sampai 6 hari. Pemberian inhibitor MMP9 menghambat migrasi SMC ke intima.( El Bedomi , 2005 )

MMP 9 merupakan enzim dengan aktivitas proteolitik terhadap gelatin dan kolagen yang terlibat pada pecahnya ECM yang merupakan salah satu penyusun plak aterosklerosis. Seberapa besar aktivitas enzim ini menunjukkan semakin besar resiko terjadinya rupture plak yang berakibat terjadinya gangguan pada vascular termasuk penyakit jantung dan pembuluh.

Katekin dengan aktivitasnya sebagai antioksidan mampu menurunkan ox-LDL yang dapat menginduksi terbentuknya beberapa sitokin yang dapat mengaktivasi jalur sinyaling melalui MAPK yang menyebabkan tingginya ekspresi MMP 9. Penurunan ekspresi MMP 9 ini menunjukkan bahwa katekin dapat digunakan sebagai agen untuk mencegah terjadinya rupture plak yang menjadi salah satu penyebab penyakit jantung dan pembuluh.

\section{Kesimpulan}

Berdasarkan hasil penelitian ini dapat disimpulkan bahwa terdapat perbedaan siknifikan ekspresi MMP9 antar kelompok perlakuan dengan kelompok DTL kecuali kelompok katekin dosis III, dan isolat golongan senyawa katekin menghambat peningkatan ekspresi MMP9 pada dosis $6 \mathrm{mg} /$ hari dan 24 $\mathrm{mg} /$ hari.

Berdasarkan hasil penelitian ini, maka perlu diteliti lebih lanjut peran TIMPs ( Tissue Inhibitor Metalo Proteins ) terhadap ekspresi MMP 9 yang merupakan factor kunci pada pathogenesis penyakit yang disebabkan oleh pecahnya ECM ( Ekstra Seluller Matriks ) termasuk penyakit jantung dan pembuluh serta peran grup IVA PLA2 ( Phospholipase A2) yang merupakan salah satu kunci pada kaskade asam arachidonat yang berpengaruh pada produksi MMP 9.

\section{Daftar Pustaka}

Anter E, et al. 2004 . Activation of Endothelial Nitric Oxide Synthase by The p38 MAPK in Response to Black Tea Polyphenols, The American Society for Biochemistry and Molecular Biology, 279(45):46637-46643.

Ali M, Muliartha IK. 2004. Optimasi Diet Tinggi Lemak pada Tikus Model Atherogenik, Jurnal Kedokteran Brawijaya: 3(2) : 1521

Aulanni'am . 2004. Prinsip dan Teknik Analisis Biomolekuler. Malang: FPUB Press.

Choo JJ. 2003. Green tea reduces body fat accretion caused by high fat diet in rats trough betaadrenoceptor activation of thermogenesis in brown adipose tissue. J. Nutr. Biochem 14 : 671-676.

DeFronzo RA. 2006. Is Insulin Resistance Atherogenic? Possible Mechanisms. Atherosclerosis. 7:11-15

DeFronzo, R.A. 2010. Insulin Resistance, Lipotoxicity, Type 2 Diabetes and Atherosclerosis : the Missing Link, Diabetologia Reviews. 53(7): 12701287.

El Bedomi, 2005. Catechins prevent vascular Smooth muscle cells invasion by inhibition MT1- MMP activity dan MMP2 ekspression. Cardiovascular research 67:317 - 325

Hsueh WA, Law RE. 2001 . PPAR $\gamma$ and atherosclerosis: effects on cell growth and movement. Arterioscler Thromb Vasc Biol 21:1891-1895

Kim J, Sears D. 2010. TRL and Insulin resistance. Gastroenterology Research and Practice. Volume 2010, 2 pages

Kim J, Formoso G, Li Y, Potenza M, A, Marasciulo F. L, Montagnani M,Quon, M.J. 2007. Epigallocatechin Gallate, A Green Tea Poliphenol, Mediates NO Dependent Vasodilatation Using Signaling Pathways in Vascular Endothelium Requiring Reactive 
Oxygen Species and Fyn J. Biol. Chem. Vol. 282, Issue 18, 13736-13745.

Klaus S, Pultz S, Thone Reineke C, Wolfram S. 2005. Epigallocathechin gallate attenuetes diet induced obesity in mice by decreasing energy absorbtion and increasing fat oxidation. Int $J$ Obes Relat Metab Disord 29 : 615-623.

Lorens M, et al. 2003. A Constituent of Green Tea, EGCG, Activates eNOS by a Phosphatidylinositol-3- $\mathrm{OH}-$ kinase, cAMP- Dependent Protein Kinase, and Akt- Dependent Pathway and Leads to Endothelial Dependent Vasorelaxation. J Biol Chem. 279(7) : 6190-6195.

Murase T, Haramizu S, Shimotoyodome A, Nagasawa A, Tokimitsu I . 2005. Green tea extract improves endurance capacity and increases muscle lipid oxidation in mice. Am J Physiol Regul Integr Comp Physiol 288 : R708-R715.

Muniyappa R, Montagnani M, Kon Koh K, Guon, MJ. 2007. Cardiovascular Actions of Insulin. Endocrine Reviews. 28 (5) : 463-491.

Pederson, TM, Kramer DL, Rondinone CM., 2001. Serin/ Threonin Phosphorylation of IRS-1 triggers its degradation, possible regulation by tyrosin phosphorylation, Diabetes $50: 24-31$.

Roden M, et. Al. 1996. Mechanism of Free Fatty Acid Induced Insulin Resistance in Humans. J. Clin Invest. 97(12):2859-65.

Schrauwen P. 2007. High Fat Diet, Muscular Lipotoxicity and Insulin Resistance, Proceedings of the Nutrition Society, 66(1):33-41

Velayutam P. Babu and Liu. 2008. Green Tea Catechins and Cardiovascular Health ; An Update, Current Medicinal Chemistry, vol 15. No. 18 : 1840-1850

World Health Organization. 2003. Deaths from coronary heart disease, International Society of Hypertension Writing Groups, J. Hypertension . Vol $21 \quad$ No.11.p 1983-1992 http://www.who.int/cardiovascular_dis eases/en/cvd_atlas_14_deathHD

Yang Z, Ming XF . 2006. Recent Advances in Understanding Endothelial Dysfunction in Atherosclerosis, Clinical Medicine \& Research Review. 4(1): 53-65. 